University of Nebraska - Lincoln

DigitalCommons@University of Nebraska - Lincoln

\title{
Age-distribution estimation for karst groundwater: Issues of parameterization and complexity in inverse modeling by convolution
}

Andrew J. Long

U.S. Geological Survey, ajlong@usgs.gov

Larry D. Putnam

U.S. Geological Survey

Follow this and additional works at: https://digitalcommons.unl.edu/usgsstaffpub

Part of the Earth Sciences Commons

Long, Andrew J. and Putnam, Larry D., "Age-distribution estimation for karst groundwater: Issues of parameterization and complexity in inverse modeling by convolution" (2009). USGS Staff -- Published Research. 428.

https://digitalcommons.unl.edu/usgsstaffpub/428

This Article is brought to you for free and open access by the US Geological Survey at DigitalCommons@University of Nebraska - Lincoln. It has been accepted for inclusion in USGS Staff -- Published Research by an authorized administrator of DigitalCommons@University of Nebraska - Lincoln. 


\title{
Age-distribution estimation for karst groundwater: Issues of parameterization and complexity in inverse modeling by convolution
}

\author{
Andrew J. Long *, Larry D. Putnam \\ US Geological Survey, 1608 Mountain View Rd, Rapid City, SD 57702, United States
}

\section{A R T I C L E I N F O}

\section{Article history:}

Received 20 November 2008

Received in revised form 2 June 2009

Accepted 30 July 2009

This manuscript was handled by P. Baveye, Editor-in-Chief

\section{Keywords:}

Groundwater

Karst

Parameter estimation

Inverse modeling

Groundwater age

\begin{abstract}
S U M M A R Y
Convolution modeling is useful for investigating the temporal distribution of groundwater age based on environmental tracers. The framework of a quasi-transient convolution model that is applicable to twodomain flow in karst aquifers is presented. The model was designed to provide an acceptable level of statistical confidence in parameter estimates when only chlorofluorocarbon (CFC) and tritium $\left({ }^{3} \mathrm{H}\right)$ data are available. We show how inverse modeling and uncertainty assessment can be used to constrain model parameterization to a level warranted by available data while allowing major aspects of the flow system to be examined. As an example, the model was applied to water from a pumped well open to the Madison aquifer in central USA with input functions of CFC- 11, CFC-12, CFC-113, and ${ }^{3} \mathrm{H}$, and was calibrated to several samples collected during a 16-year period. A bimodal age distribution was modeled to represent quick and slow flow less than 50 years old. The effects of pumping and hydraulic head on the relative volumetric fractions of these domains were found to be influential factors for transient flow. Quick flow and slow flow were estimated to be distributed mainly within the age ranges of $0-2$ and 26-41 years, respectively. The fraction of long-term flow ( $>50$ years) was estimated but was not dateable. The different tracers had different degrees of influence on parameter estimation and uncertainty assessments, where ${ }^{3} \mathrm{H}$ was the most critical, and CFC-113 was least influential.
\end{abstract}

Published by Elsevier B.V.

\section{Introduction}

The groundwater transit time from recharge source to a well or spring (groundwater age) often is a distribution, or spectrum, of many different ages because of the dispersive properties of the aquifer, particularly in karst settings. Some karst groundwater systems are similar to a stream catchment consisting of a hierarchical drainage structure, with the main conduit acting as a drain that is hydraulically connected to a diffusive pore network or "annex system" (Palmer, 1991; Mangin, 1994). A sharp distinction between quick and slow flow is characteristic of many karst aquifers (Mangin, 1994; Pinault et al., 2001; Denić-Jukić and Jukić, 2003; Mahler and Massei, 2007). Separating these flow domains quantitatively can yield insights into major aquifer characteristics such as its degree of organization (Pinault et al., 2001), which is useful for understanding groundwater storage and contaminant transport issues.

Environmental tracers, including stable isotopes $\left({ }^{18} \mathrm{O},{ }^{2} \mathrm{H},{ }^{15} \mathrm{~N}\right)$, radionuclides $\left({ }^{3} \mathrm{H},{ }^{14} \mathrm{C},{ }^{36} \mathrm{Cl}\right.$, U-series), and dissolved gases such as chlorofluorocarbons (CFCs) and $\mathrm{SF}_{6}$, have been widely used in groundwater investigations (Cook and Herczeg, 2000). CFCs are

\footnotetext{
* Corresponding author. Tel.: +1 605394 3237; fax: +1 6053554523.

E-mail address: ajlong@usgs.gov (A.J. Long).
}

anthropogenic tracers present in the atmosphere that are useful for estimating groundwater age (Cook et al., 1996; Oster et al., 1996; Plummer et al., 2006). CFCs enter groundwater with infiltrating precipitation or sinking streams. Groundwater age can be estimated by comparing concentrations in groundwater samples to historical atmospheric concentrations for different CFC species including CFC-11, CFC-12, and CFC-113 (Fig. 1). CFCs in rainwater and surface water become equilibrated with atmospheric concentrations; in groundwater not in contact with the open atmosphere (saturated or confined zones), CFCs generally remain at the concentration of recharge water, except in reducing environments. Groundwater in some vadose zones can remain in equilibrium with atmospheric concentrations, and thus long residence times of infiltrating water in the vadose zone can affect the age interpretation. Fast infiltration in karst aquifers is less susceptible to this effect. Because the atmospheric tritium $\left({ }^{3} \mathrm{H}\right)$ concentrations in past decades were elevated when CFC concentrations were low, the old water fraction ( $>50$ years old) can be better constrained with the combination of these tracers (Plummer et al., 2006), which will be demonstrated in this paper for modeling age distributions.

Methodologies for interpreting age-dating tracers and age distributions for steady state and transient groundwater applications are described in Maloszewski and Zuber (1991), Goode (1996), Varni and Carrera (1998), Pinault et al. (2001), and Corcho Alvarado 


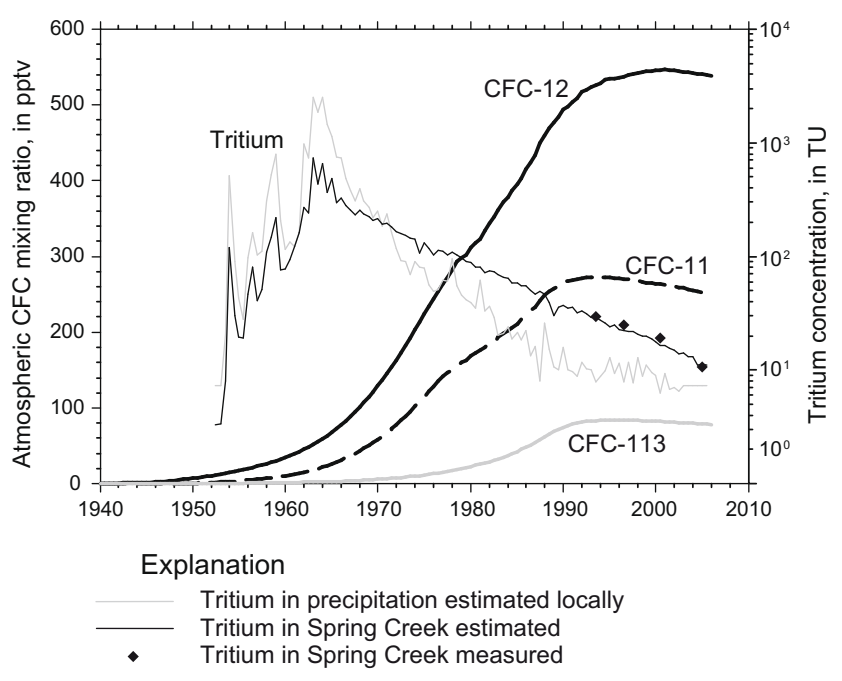

Fig. 1. Chlorofluorocarbon (CFC) mixing ratios measured in the atmosphere and tritium concentrations estimated locally in precipitation and in Spring Creek. Atmospheric CFC mixing ratios for North America were from Plummer and Busenberg (2006). Tritium concentrations in precipitation for the Black Hills, South Dakota were estimated by Putnam and Long (2007b). Measured and estimated tritium concentrations in Spring Creek are described in this paper. [pptv, parts per trillion by volume; TU, tritium units].

et al. (2007). Convolution (or lumped-parameter) modeling is an effective tool for analyzing many natural systems, including groundwater flow and transport, and is particularly useful for analysis in karst aquifers (Mangin, 1994; Olsthoorn, 2008). Previous computer programs suitable for basic applications in convolution modeling of environmental tracers in groundwater are available and include Maloszewski and Zuber (1996), Böhlke (2004), and Ozyurt and Bayari (2005).

Pinault et al. (2001) modeled a two-domain karst system by convolution with two superposed impulse-response functions that represent the two domains. Denic-Jukic and Jukic (2003) used a composite impulse-response function, which combined the peak of the quick-flow function with the tail of a slow-flow function. Long and Putnam (2006) applied a steady-state convolution model to CFC data (one-time sampling) for a karst aquifer and concluded that CFC concentrations for samples from several wells were the result of bimodal age distributions that represented quick-flow and slow-flow domains. However, because these CFC data alone were not sufficient to estimate parameters with quantifiable uncertainty, inverse modeling was not conducted, and only general characteristics of probable age distributions were discussed. In this paper we show that by including ${ }^{3} \mathrm{H}$ data together with CFC data in a quasi-transient model, the problem is better constrained, and a limited number of parameters can be estimated by inverse methods with quantifiable confidence limits and assessment of model uncertainty. Determination of the optimum level of model parameterization is needed for obtaining meaningful results but is an illdefined process (Hill, 2006) and one which we propose to better define for modeling age distributions when data are sparse. Hill (2006) stresses the importance of parsimony in these situations, and further guidelines for effective model calibration are in Anderson and Woessner (1992), and Gallagher and Doherty (2007).

The objectives of this study were to develop a method for estimating age distributions for discharge from a karst aquifer with multiple flow components and to explore methods for determining appropriate levels of model parameterization. This method can be used to help assess aquifer organization, transient flow dynamics, and solute transport issues. The approach presented herein is a quasi-transient convolution model with an age distribution that includes two superposed parametric functions applicable to two- domain karst aquifers and accounts for transient effects of hydraulic head and pumping. As an example, we describe an application of the model with quick-flow and slow-flow domains.

Four input functions for recharge water were used in the model: the three atmospheric CFC curves and the estimated ${ }^{3} \mathrm{H}$ concentrations in a sinking stream (Fig. 1). Modeled concentrations of the four tracers in water from a pumped well were calibrated to measured concentrations in several samples collected sparsely during a 16-year period. This provides an example of how inverse modeling and uncertainty assessment can be used to constrain parameterization to a level that is warranted by available data. Because CFCs and ${ }^{3} \mathrm{H}$ are common tracers used for dating groundwater in the range of $0-50$ years old, this approach may have potential for broad practical application for cases where tracer input functions are known or can be estimated.

\section{The convolution model for groundwater age}

The convolution integral applied to groundwater tracers can be expressed as (Olsthoorn, 2008)

$c(t)=\sum_{i=0}^{\infty}\left[c_{i n}\left(t-\tau_{i}\right) \Delta \tau_{i}\right] g\left(\tau_{i}\right) \exp \left(-\lambda \tau_{i}\right)$.

Eq. (1) describes the tracer concentration at the discharge point $c(t)$ at time $t$ in response to the input tracer concentration $c_{i n}(t-\tau)$ at time $\tau$ earlier, which is weighted by the distribution of tracer age $g(\tau)\left[t^{-1}\right]$, and $\lambda\left[t^{-1}\right]$ is the decay constant for radioisotope tracers. ${ }^{3} \mathrm{H}$ has a half-life of 12.43 years, which results in a decay constant $\lambda$ of $0.0558 \mathrm{yr}^{-1}$. CFCs are radiometrically stable tracers for which $\lambda$ is equal to zero. This form of the convolution equation engages $g(\tau)$ as a weighting function applied to past input values and calculates the output concentration based on the age distribution for a particular time step. Thus $g(\tau)$ can take on a different form for each time step if required for transient applications. For modeling CFC and ${ }^{3} \mathrm{H}$ concentrations, $c_{i n}(t)$ is the long-term record of tracer concentrations in recharge water. These tracers are assumed to be conservative, and thus $g(\tau)$ is an approximation of groundwater age. When $c_{i n}(t)$ and $c(t)$ are known, $g(\tau)$ can be estimated by inverse modeling.

Maloszewski and Zuber (1991) described the dispersion function and its applications for transport in fissured carbonate aquifers:

$g(\tau)=\frac{P^{1 / 2}}{\bar{t}\left[4 \pi(\tau / \bar{t})^{3}\right]^{1 / 2}} \exp \frac{-P(1-\tau / \bar{t})^{2}}{4(\tau / \bar{t})}$

where $\bar{t}$ is the mean transit time, $P$ is the dimensionless Peclet number that describes the dispersive properties of the aquifer and is analogous to the variance of a normal distribution because the distribution width, or age span, resulting from mechanical dispersion is proportional to $P$. When input and output dimensions are equivalent, the area under the curve for the age distribution is unity. For this approach, two dispersion functions are used to represent the two flow domains, and by superposition

$g(\tau)=a_{q} g_{q}(\tau)+a_{s} g_{s}(\tau) \quad\left(a_{q}+a_{s} \leqslant 1\right)$,

where $a_{q}$ and $a_{s}$ are positive, dimensionless, and represent the relative volumetric fractions for quick and slow flow, respectively. Cases where $a_{q}+a_{s}<1$ results either from model error or the presence of an older flow domain, in which case $\left(a_{q}+a_{s}+a_{l}=1\right)$, where $a_{l}$ is the fraction of long-term flow (age $>50$ years). The age of the long-term domain, however, cannot be determined. Transient conditions can be modeled by allowing some or all of the parameters of the age distribution to change temporally based on hydraulic influences. 
Mahler and Massei (2007) concluded that the relative rates of quick and slow flow were influenced by changes in hydraulic head. The pumping rate from wells also can influence groundwater age (Zinn and Konikow, 2007). A karst conduit can be compared to a surface-water stream, where a nearby pumped well influences streamflow (or conduit flow). Some wells deplete streamflow approximately synchronous with pumping (Bredehoeft and Kendy, 2008). If the conduit flow fraction can be assumed to change linearly in proportion to hydraulic head and pumping, then the value of $a_{q}$ can be estimated as a function of time by the equation

$a_{q}(t)=\Psi_{q} q(t)+m_{q} h(t)+b_{q}$

where $h(t)$ is hydraulic head [length $\mathrm{L}$ ], $m_{q}$ is a coefficient that weights the influence of hydraulic head $\left[\mathrm{L}^{-1}\right], q(t)$ is the pumping rate $\left[\mathrm{L}^{3} / t\right], \psi_{q}$ is a coefficient that weights the influence of pumping $\left[t / \mathrm{L}^{3}\right]$, and $b_{q}$ is a function shift parameter [dimensionless]. The parameter $b_{q}$ is necessary to compensate for an arbitrarily selected altitude at which $h=0$ (e.g., sea level). Depending on the application, hydraulic head might be a proxy for recharge, or recharge could be used in place of $h(t)$. Here, hydraulic head does not refer to water level in or near the well (i.e., water affected by pumping of that well), but to hydraulic head outside of the well's zone of drawdown, which might influence the well's discharge. Similarly, the value of $a_{s}$ can be determined as a function of time by the equation

$a_{s}(t)=\Psi_{s} q(t)+m_{s} h(t)+b_{s}$.

Hence, by linking $a_{q}$ and $a_{s}$ with hydrologic time-series data, only five parameters are required for estimating values of $a_{q}$ and $a_{s}$ for all time steps.

The sign of the weighting coefficients indicates whether pumping and hydraulic head have a direct or inverse effect on $a$. The absolute value of $\psi_{q}$ compared with $\psi_{s}$ indicates the relative effect of pumping on quick and slow flow, and the same is true for $m_{q}$ and $m_{s}$ in relation hydraulic head. Other stresses that might affect flow fractions include climate change and conduit dissolution.

\section{Model application}

The study area

This model was applied to CFC and ${ }^{3} \mathrm{H}$ data for a supply well (RC11) open to the Madison aquifer on the eastern flank of the Black Hills of South Dakota (Fig. 2). This well produces as much as $700,000 \mathrm{~m}^{3} / \mathrm{yr}$ of water (Fig. 3). The Mississippian-age Madison Limestone (locally, the Pahasapa Formation) is exposed at the land surface in the mountainous western part of the study area and dips to the east. An ancient epikarst clay soil exists on the surface of the eroded and buried Madison Limestone (Gries, 1996). The outcrop has thin soil cover or none. The formation is more than $140 \mathrm{~m}$ thick at well RC11 and contains limestone and dolostone. Flow primarily is parallel to bedding and occurs within large conduits and other solution openings of various sizes, primarily within the upper 30-60 m (Greene, 1993; Ford et al., 1993). The Madison aquifer is partially confined above by the low-permeability shale layers of the Minnelusa Formation (Permian and Pennsylvanian; $\sim 200 \mathrm{~m}$ thick), which also contains sandstone and limestone, and below by the lower $80-110 \mathrm{~m}$ of the Madison Limestone, which has very low permeability (Driscoll et al., 2002; Rahn and Gries, 1973). Underlying the Madison Limestone is the Englewood Limestone (Devonian, 10-20 m thick), which is a confining unit (Greene, 1993). The top of the Madison aquifer is $255 \mathrm{~m}$ deep at well RC11, and the well is open hole from 269 to $391 \mathrm{~m}$, which penetrates the lower part of the Madison Limestone. The well is artesian with a static water level about $235 \mathrm{~m}$ above the top of the aquifer. The well was completed in 1991 and was finished above the open hole with steel pipe ( $0.34 \mathrm{~m}$ diameter) and concrete grout. Land use is urban residential near well RC11 and primarily rural near Spring Creek.

Recharge to the Madison aquifer in the study area largely is from Spring Creek and Rapid Creek (flowing east), which sink into the Madison Limestone within the outcrop area (Fig. 2). Upstream from the Madison Limestone, the catchments for these streams consist primarily of fractured Precambrian rocks. From 19862007, monthly mean streamflow varied from $0.15 \mathrm{~m}^{3} / \mathrm{s}$ for January

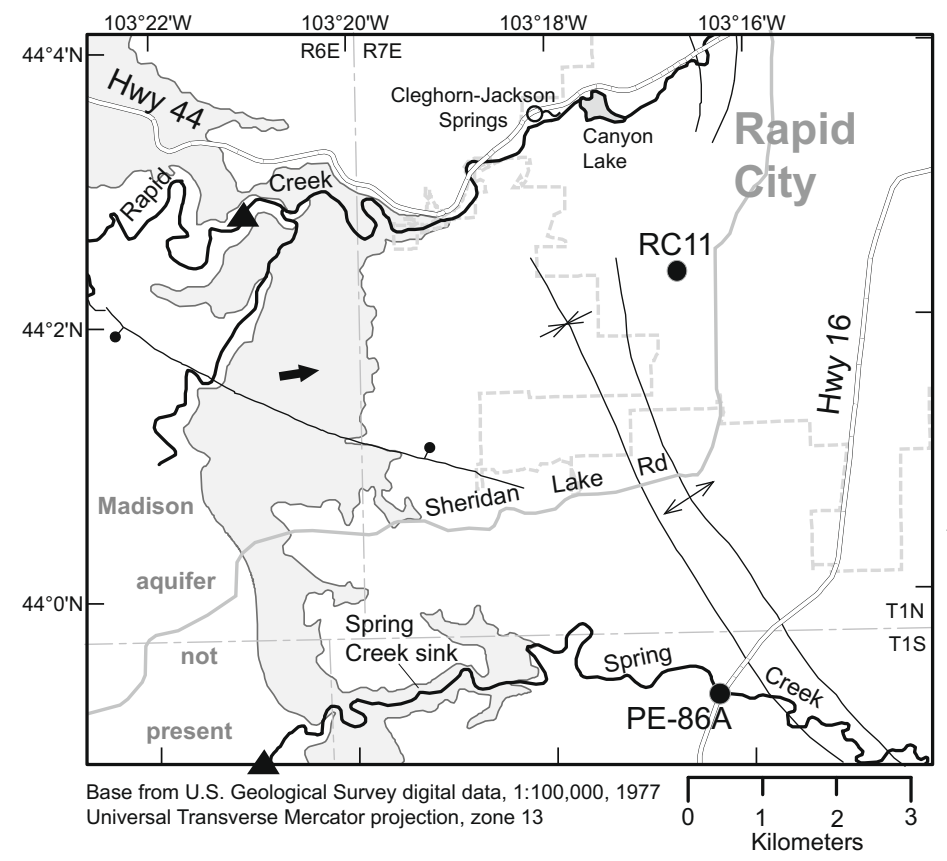

Explanation

Madison Limestone outcrop (Strobel et al., 1999)

O Spring

- Sampled well open to the Madison aquifer

- Streamflow gage

$\rightarrow$ General dip direction of Madison Limestone Rapid City limits

Structural features

- Fault-Bar and ball on downthrown side Anticline-Showing trace of axial plane Syncline-Showing trace of axial plane t
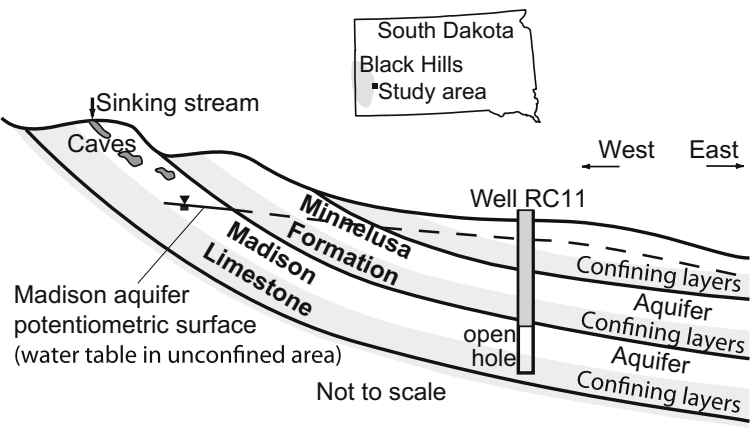

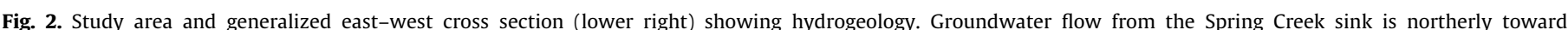

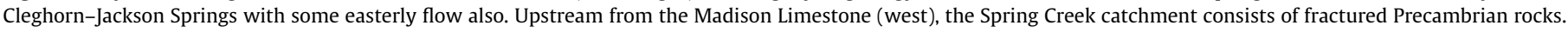
(see above-mentioned references for further information) 


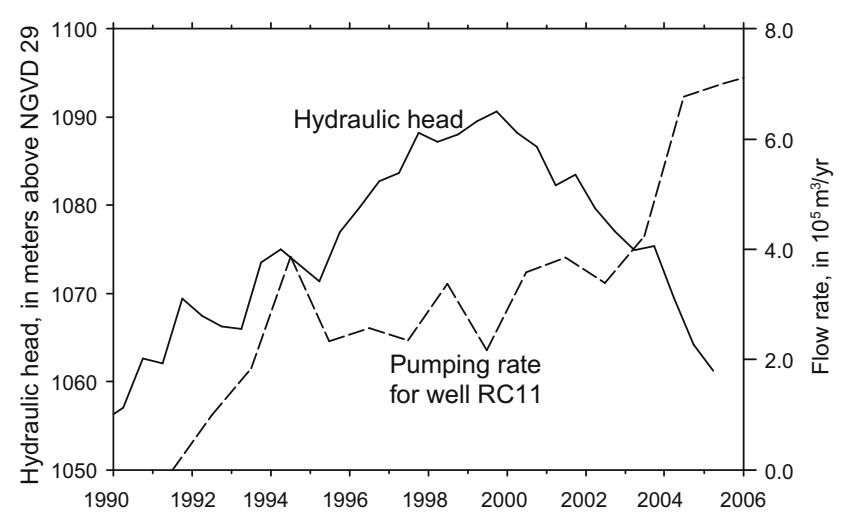

Fig. 3. Hydraulic head in well PE-86A and pumping rate for well RC11. [NGVD 29, National Geodetic Vertical Datum of 1929].

to $2.0 \mathrm{~m}^{3} / \mathrm{s}$ for June at the gage on Spring Creek, and the mean, median, and standard deviation of daily flows were $0.56,0.18$, and $1.26 \mathrm{~m}^{3} / \mathrm{s}$, respectively (Fig. 2, station 06407500, USGS 2007). The maximum rate of sinking streamflow to the Madison Limestone is about $0.6 \mathrm{~m}^{3} / \mathrm{s}$ (Hortness and Driscoll, 1998). Precipitation in the outcrop area is about $48 \mathrm{~cm} / \mathrm{yr}$ with the highest precipitation rates generally occurring from March through June (Driscoll et al., 2000). Infiltration of precipitation within the outcrop is an additional source of recharge that accounts for less than $10 \%$ of total recharge in the area (Long and Putnam, 2002). Several studies of artificial tracers injected into sinking streams in the Black Hills have resulted in breakthrough curves that return to background concentrations within 1-2 years for wells open to the Madison aquifer (Greene, 1999; Putnam and Long, 2007a). Many of these wells, including well RC11, had CFC apparent ages in the decades old range, which indicates the presence of water much older than what is represented by these breakthrough curves. Spring Creek flows exceeding $0.6 \mathrm{~m}^{3} / \mathrm{s}$ partially sink into the Minnelusa aquifer (Hortness and Driscoll, 1998), which overlies the Madison aquifer and is exposed at the land surface to the east of the Madison Limestone.
On the basis of the analysis of stable isotopes of oxygen and hydrogen, a predominant groundwater flow path originates at the Spring Creek sink and flows north toward Jackson-Cleghorn Springs (Anderson et al., 1999; Naus et al., 2001). These isotopes also indicate that $89-100 \%$ of water sampled from well RC11 was recharged by Spring Creek (Greene, 1997; Fig. 2). On this basis, we assume that $90-100 \%$ of the water from well RC11 originates from Spring Creek recharge. Hydraulic head in the Madison aquifer declines by about $30 \mathrm{~m}$ from the stream sink to well RC11, a distance of about $7 \mathrm{~km}$. Hydraulic head measurements for well PE$86 \mathrm{~A}$ and the pumping rate from well RC11 were used in Eqs. (4) and (5) to estimate the relative flow domain contributions to the well (Fig. 3). Well PE-86A is outside of the zone of influence of well RC11.

\section{Sampling}

Water samples for the analysis of CFCs and ${ }^{3} \mathrm{H}$ were collected from well RC11 and Spring Creek upstream from the sink during 1991-2006 (Table 1). All sample bottles were filled with untreated, unfiltered water without atmospheric contact. These samples were collected after temperature, electrical conductivity, and $\mathrm{pH}$ had stabilized. The well was pumped with a designated submersible pump used for water production, and refrigeration grade copper tubing was used as the sampling line. For each CFC sample, five bottles were filled, of which three were analyzed (replicate samples) for quality control. The averages of the three replicate samples were used as the measured sample concentration for model calibration (Table 1). The variation in measured concentration for each set of replicate samples was represented by the difference of the maximum and minimum concentrations divided by the mean. These relative percent differences (RPD) were in the range of $2.1-3.6 \%$ for CFC-11, 2.3-13.3\% for CFC-12, and $3.3-21.4 \%$ for CFC-113 (Table 1).

To verify that stream water had equilibrated with the atmosphere, CFC samples were collected from Spring Creek at the streamflow gage (Fig. 2) on 25 May 2006. Mixing ratios for CFC12 and -113 (Table 1 ) were similar to current atmospheric mixing ratios (Fig. 1). CFC-11 was higher than atmospheric mixing ratios,

Table 1

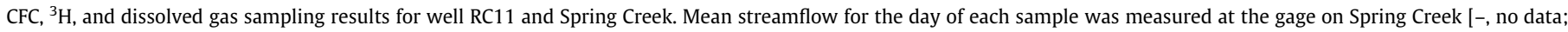
pptv, parts per trillion by volume; TU, tritium units; $\mathrm{mg} / \mathrm{L}$, milligrams per liter].

\begin{tabular}{|c|c|c|c|c|c|c|c|c|c|c|}
\hline \multirow[t]{2}{*}{ Sample date } & \multirow[t]{2}{*}{${ }^{3} \mathrm{H}(\mathrm{TU})^{\mathrm{b}}$} & \multirow[t]{2}{*}{${ }^{3} \mathrm{H} \pm 2 \sigma(\mathrm{TU})^{\mathrm{c}}$} & \multicolumn{3}{|c|}{ CFC mixing ratio (pptv) } & \multicolumn{3}{|c|}{$\begin{array}{l}\text { Relative \% difference for three } \\
\text { replicate samples }\end{array}$} & \multirow{2}{*}{\multicolumn{2}{|c|}{ Streamflow $\left(\mathrm{m}^{3} / \mathrm{s}\right)^{\mathrm{b}}$}} \\
\hline & & & CFC $-11^{\mathrm{a}}$ & $\mathrm{CFC}-12^{\mathrm{a}}$ & $\mathrm{CFC}-113^{\mathrm{a}}$ & CFC-11 & CFC -12 & CFC-113 & & \\
\hline \multicolumn{11}{|l|}{ Well RC11 samples } \\
\hline 17 December 1991 & 10.7 & 0.9 & - & - & - & - & - & - & & \\
\hline 5 October 1993 & 16.6 & - & - & - & - & - & - & - & & \\
\hline 21 April 1995 & - & - & 63.7 & 140.2 & 13.9 & $3.6 \%$ & $2.3 \%$ & $12.5 \%$ & & \\
\hline 24 July 1996 & 16.0 & 0.9 & - & - & - & - & - & - & & \\
\hline 19 July 2000 & 12.0 & 0.8 & 100.0 & 230.2 & 62.1 & $2.1 \%$ & $7.4 \%$ & $21.4 \%$ & & \\
\hline 20 October 2005 & 9.4 & 0.6 & 130.4 & 266.1 & 34.3 & $3.0 \%$ & $13.3 \%$ & $3.3 \%$ & & \\
\hline \multicolumn{11}{|l|}{ Spring Creek samples } \\
\hline 27 September 1993 & 29.7 & - & - & - & - & - & - & - & & \\
\hline 9 September 1996 & 25.1 & 1.6 & - & - & - & - & - & - & & \\
\hline 6 June 2000 & 19.1 & 1.2 & - & - & - & - & - & - & & \\
\hline 6 May 2005 & 10.7 & 0.8 & - & - & - & - & - & - & & \\
\hline \multirow[t]{3}{*}{25 May 2006} & - & - & 321.8 & 554.1 & 76.2 & $19.3 \%$ & $5.4 \%$ & $3.0 \%$ & & \\
\hline & \multicolumn{5}{|c|}{ Dissolved gases $(\mathrm{mg} / \mathrm{L})$} & \multicolumn{5}{|c|}{ Relative \% difference for two replicate samples } \\
\hline & $\mathrm{CH}_{4}$ & $\mathrm{~N}_{2}$ & & & $\mathrm{Ar}$ & $\mathrm{CH}_{4}$ & & & $\mathrm{O}_{2}$ & $\mathrm{Ar}$ \\
\hline \multicolumn{11}{|l|}{ Well RC11 samples } \\
\hline 20 October 2005 & 0.00 & 19.12 & & & 0.663 & $0.0 \%$ & & & $1.8 \%$ & $0.7 \%$ \\
\hline 20 October 2005 & 0.00 & 19.02 & & & 0.659 & & & & & \\
\hline
\end{tabular}

\footnotetext{
a Concentrations were averaged from three replicate samples.

b Data from the National Water Information System (US Geological Survey, 2008) and Naus et al. (2001).

c Indicates the accuracy to the measurement as \pm two standard deviations.
} 
which indicates possible contamination, the source of which might be septic systems within several meters of the stream. Between this location and the main stream sinks $(4 \mathrm{~km})$ there are no septic systems in such proximity to the stream, and the elevated CFC-11 mixing ratios at the sample location would have time to equilibrate with the atmosphere. Also, the RPD for that sample (19.3\%) was notably high (Table 1) and may indicate other sources of error, such as contamination during sample collection. The RPD for the CFC-113 sample for well RC11 in 2000 also was high (21.4\%) and could result in model error. Unlike CFCs, ${ }^{3} \mathrm{H}$ in surface water does not equilibrate with atmospheric concentrations, and thus ${ }^{3} \mathrm{H}$ concentrations in Spring Creek result from a mixture of recent precipitation and base flow. ${ }^{3} \mathrm{H}$ samples collected from Spring Creek from 1993 to 2005 were used to estimate a long-term ${ }^{3} \mathrm{H}$ record for Spring Creek (Fig. 1, Table 1) as explained in detail in the Appendix A.

Samples for the analysis of the dissolved gases $\mathrm{CH}_{4}, \mathrm{O}_{2}, \mathrm{~N}_{2}$, and Ar were collected from well RC11 concomitant with the 2005 CFC sample (Table 1). Concentrations of these gases were used to assess possible CFC degradation and to improve the estimates of CFCbased groundwater ages by applying methods described by Plummer and Busenberg (1999), where the recharge temperature was estimated to be $8.2^{\circ} \mathrm{C}$. The presence of $\mathrm{O}_{2}$ and the absence of methane in samples (Table 1 ) indicates aerobic groundwater and that CFC degradation did not occur. Dissolved CFC concentrations in water samples reported by the laboratory were converted to equivalent air mixing ratios for comparison to atmospheric mixing ratios. For this conversion, Henry's Law applies, which states that the concentration of a gas dissolved in water in equilibrium with air is proportional to the partial pressure of the gas in air (Plummer and Busenberg, 1999).

Samples were analyzed at the US Geological Survey (USGS) CFC Laboratory in Reston, Virginia, and the USGS Tritium Laboratory in Menlo Park, California. CFCs were determined in the laboratory using a purge-and-trap gas chromatography procedure with an electron capture detector. This instrument is calibrated to standards at the beginning and ending of each day to test for instrument stability and drift, which is typically less than $1 \%$ for CFC11 and CFC-12 and $1-3 \%$ for CFC-113. Analytical sample results are then corrected for drift. Other dissolved gases were determined by gas chromatography. ${ }^{3} \mathrm{H}$ was determined by electrolytic enrichment and liquid scintillation.

\section{Inverse modeling and parameter assessment}

The four-tracer convolution model was applied to estimate a quasi-transient age distribution based on CFC and ${ }^{3} \mathrm{H}$ data for well RC11 with 6-month time steps. The atmospheric mixing ratios for CFC-11, CFC-12, and CFC-113 were used as tracer input functions representing Spring Creek recharge. The estimated record of ${ }^{3} \mathrm{H}$ concentrations in Spring Creek (Appendix A) was used as a fourth tracer input function.

The approach involved limiting the number of parameters to what could be estimated by inverse modeling with acceptable levels of statistical confidence and model uncertainty. This level was considered acceptable when parameter values at the end points of the $95 \%$ confidence limits resulted in model outcomes that did not effectively alter overall conclusions. Parameter sensitivities and information from other tracer experiments also were considered. Inverse modeling was applied to estimate model parameters $(\bar{t}, P, m, \psi$, and $b)$ by using the parameter estimation program PEST (Doherty, 2006), which was linked to the convolution model written in FORTRAN (Eqs. (1)-(5)). Beginning with initial parameter estimates, modeled tracer concentrations $c(t)$ were calculated by the convolution model and iteratively adjusted by PEST to minimize the sum of the squared weighted residuals (SSWR); i.e., the differences between measured and modeled values. This process determined the best-fit parameter values and confidence intervals for those values by applying a nonlinear estimation technique known as the Gauss-Marquardt-Levenberg method (Levenberg, 1944; Marquardt, 1963 Doherty, 2006).

The model was calibrated to 14 measured values for samples from well RC11. These include nine CFC concentrations and five ${ }^{3} \mathrm{H}$ concentrations (Table 1 ). If $\bar{t}_{q}, \bar{t}_{s}, P_{q}$, and $P_{s}$ were to be estimated for each of the six sample times, the total number of parameter values to be estimated would be 30 , which is much greater than the number of measurements. This would result in an under-constrained model and very little confidence in parameter estimates. We hypothesized that parameters affecting the relative magnitudes of flow fractions would be the most critical in modeling and understanding transient phenomena (e.g., see Mahler and Massei, 2007), whereas parameters affecting the exact positions in time of these flow fractions ( $\bar{t}$ and $P$ ) would be less critical and possibly could be assumed constant. Therefore, $\bar{t}_{q}, \bar{t}_{s}, P_{q}$, and $P_{s}$ were initially assumed to be constant, which reduced the number of parameter values to 10 . This hypothesis was examined further by an analysis of parameter sensitivity and confidence limits to assess the validity of accepting this as a model assumption (see subsequent discussions).

The initial PEST execution resulted in very large confidence intervals for $\bar{t}_{q}$ and $P_{q}$, which indicated low confidence in the quick-flow distribution. Also, several parameters were highly correlated (correlation coefficient $>0.9$ ). CFC-based ages have large uncertainties in very young groundwater due to flattening of the atmospheric CFC curves after about 1990 (Fig. 1, Plummer and Busenberg, 1999). It was thus evident that precise estimates of the quick-flow distribution would not be possible. This estimate of the quick-flow distribution, however, was consistent with artificial tracer studies in the area as previously discussed because the distribution was contained within the first 2 years. Therefore, $\bar{t}_{q}$ and $P_{q}$ were assigned the fixed values of two time steps ( 1 year) and 5.9, respectively, for consistency with these studies and thus were omitted from further adjustments in PEST. Therefore, it was accepted that there would be little statistical confidence in these parameters based on model fit alone, but that there would be some confidence in them based on prior information.

Further PEST executions indicated that $b_{q}$ and $b_{s}$ could be assumed to have equal absolute values with opposite signs, where

Table 2

Estimated parameter values for samples from well RC11. Time dimensions were converted from time steps to years [m, meters; yr, year; NA not applicable].

\begin{tabular}{|c|c|c|c|c|c|}
\hline \multirow[t]{2}{*}{ Parameter } & \multirow[t]{2}{*}{ Flow domain } & \multirow[t]{2}{*}{ Parameter value } & \multicolumn{2}{|c|}{ 95\% Confidence limits } & \multirow[t]{2}{*}{ Dimensions } \\
\hline & & & Lower limit & Upper limit & \\
\hline $\bar{t}_{s}$ & Slow flow & 32.9 & 30.9 & 35.1 & $\mathrm{yr}$ \\
\hline$P_{s}$ & Slow flow & 310.9 & 76.9 & 1256.0 & Dimensionless \\
\hline$m_{q}$ & Quick flow & $5.6 \times 10^{-3}$ & $2.3 \times 10^{-3}$ & $8.9 \times 10^{-3}$ & $\mathrm{~m}^{-1}$ \\
\hline$m_{s}$ & Slow flow & $-5.3 \times 10^{-3}$ & $-8.5 \times 10^{-3}$ & $-2.0 \times 10^{-3}$ & $\mathrm{~m}^{-1}$ \\
\hline$b_{q}$ & Quick flow & -5.29 & -9.49 & -2.35 & Dimensionless \\
\hline$\Psi_{q}$ & Quick flow & $6.4 \times 10^{-7}$ & $4.4 \times 10^{-7}$ & $8.4 \times 10^{-7}$ & $\mathrm{yr} / \mathrm{m}^{3}$ \\
\hline$\Psi_{s}$ & Slow flow & $-2.1 \times 10^{-7}$ & $-5.9 \times 10^{-7}$ & $1.7 \times 10^{-7}$ & $\mathrm{yr} / \mathrm{m}^{3}$ \\
\hline
\end{tabular}


$b_{s}=-b_{q}$ so that only one parameter need be estimated. With the tentative assumptions at this point in the process, the remaining seven parameter estimates and 95\% confidence intervals were determined by a PEST execution (Table 2). Time dimensions for all results were converted from time steps of 6 months to years for purposes of description.

Results

The modeled age distribution was bimodal and indicates that slow flow ranged from about 26 to 40 years, a span of 14 years (Fig. 4). An error analysis for this age span based on parameter confidence limits (Table 2) indicates that the overall distribution is not different to large degree when considered at these limits. At these $95 \%$ confidence limits, the calibrated age span of 14 years ranges from 9 to 32 years, and the distinct separation of quick and slow flow remains intact. Parameters $\bar{t}_{s}$ and $P_{s}$ had relatively low sensitivity as compared with other parameters indicating that the error bars on the age span might be much wider if these parameters were not held constant, which would result in greater parameter uncertainty. Therefore, it was accepted that temporal changes in $\bar{t}_{s}$ and $P_{s}$ might result in the aforementioned changes in the slowflow distribution but that these changes could not be quantified with acceptable model confidence, and the inclusion of these parameters as constant was accepted.

During the modeled period (1990-2005), the quick-flow fraction increased from 0.04 to 0.55 , whereas the long-term fraction decreased from 0.59 to 0.28 . The slow-flow fraction ranged from 0.12 to 0.36 , with a decrease during the first part of the period followed by a slight increase (Fig. 5). These simulated changes resulted primarily from the combined effects of simulated hydraulic head and pumping changes. Figs. 6 and 7 show the model fit to measured concentrations. The sample with the poorest fit was CFC-113 in 2000 (Fig. 6). We note that this also was the sample with the largest relative percent difference in the three replicates as previously discussed, and thus sample error may have been a factor in the poor fit for this sample. Aside from this, CFC-113 was shown to have the least affect on model outcome as will be described in the sensitivity analysis.

\section{Sensitivity of tracers and parameters}

Inverse modeling places constraints on model complexity because uncertainty assessments help to determine how many parameters can be included based on the quality and quantity of measurements and the relative influence of the different tracers

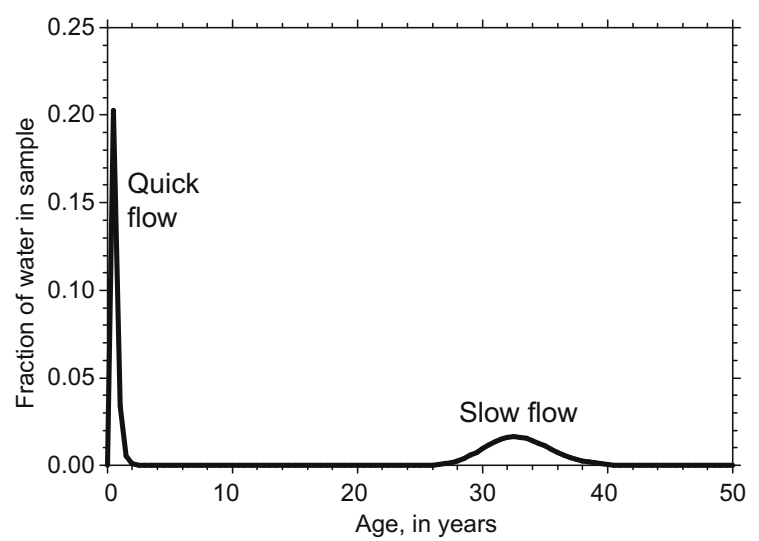

Fig. 4. Model-calibrated distribution of groundwater age from well RC11 using average flow-domain fractions for 1990-2005. When considering parameter confidence intervals, the slow-flow age span could be as wide as 32 years $(P=76.9)$ or as narrow as 9 years $(P=1256)$. for a particular application. To examine this issue, the relative effects of each of the four tracers on model calibration and uncertainty were evaluated by four inverse modeling executions, each omitting one tracer. When CFC- 11 and CFC- 12 were omitted, confidence intervals were larger. Omitting CFC-113 had little effect on confidence limits suggesting that CFC-113 had less influence for the estimated parameters. One reason for this could be the small slope of the CFC-113 input function (Fig. 1) or the analytical error for CFC-113 (larger than CFC-11 and -12) and thus may have implications for other study areas. Omitting ${ }^{3} \mathrm{H}$ resulted in considerably

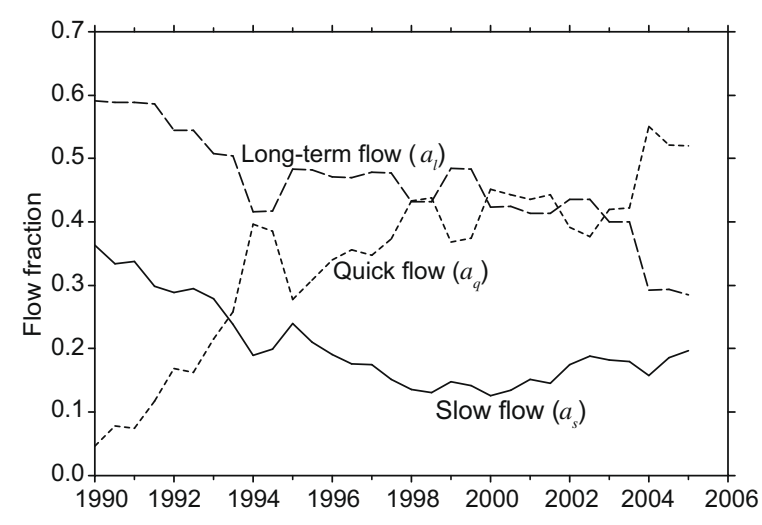

Fig. 5. Modeled values for quick, slow, and long-term flow fractions.

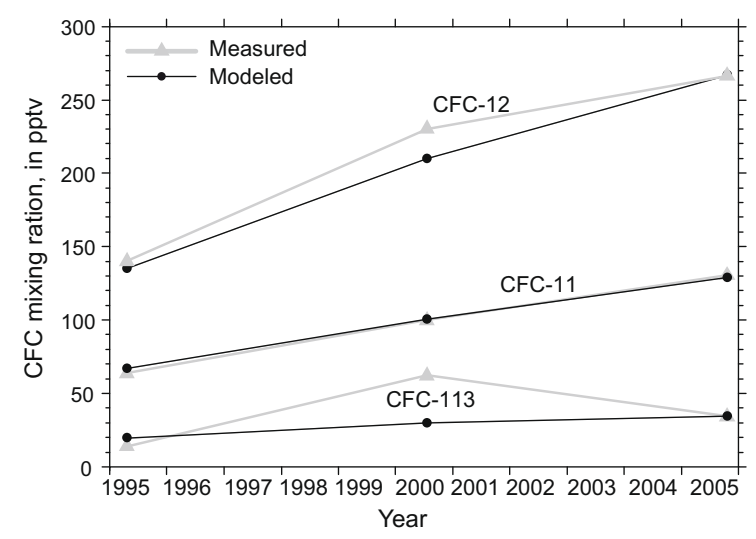

Fig. 6. Measured and modeled CFC concentrations for samples from well RC11. [pptv, parts per trillion by volume].

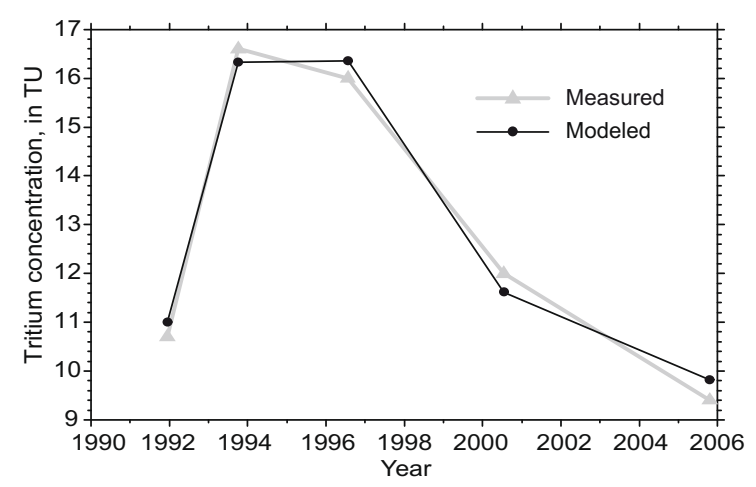

Fig. 7. Measured and modeled ${ }^{3} \mathrm{H}$ concentrations for samples from well RC11. 
larger confidence intervals, particularly for $\bar{t}_{s}$ and $P_{s}$, where the confidence limits spanned many orders of magnitude. This indicates that ${ }^{3} \mathrm{H}$ was essential for the analysis, particularly in defining the slow-flow domain, because of the very different characteristics of the ${ }^{3} \mathrm{H}$ input function as compared with the CFC curves as discussed by Plummer et al. (2006). To evaluate the effects of timeseries data for modeling transient phenomena, an age distribution for the 2005 samples only (steady state) was estimated as a comparison. This required the estimation of only four parameters $\left(\bar{t}_{s}\right.$, $P_{s}, a_{q}$, and $a_{s}$ ) calibrated to four measurements. Results of the PEST execution indicated that this model was under-constrained because confidence intervals could not be calculated. When one of the four parameters was assigned a fixed value (not estimated), confidence intervals could be calculated on the remaining three. Four tracers may have been too few for estimating four parameters in this case because of the small influence of CFC-113. Results might be different if a different tracer, such as $\mathrm{SF}_{6}$ or ${ }^{85} \mathrm{Kr}$ (not available here), was used in place of CFC-113.

A parameter sensitivity analysis indicates that the model was most sensitive to parameters related to the influence of hydraulic head $\left(m_{q}, m_{s}, b_{q}\right)$, whereas parameters related to the influence of pumping $\left(\psi_{q}, \psi_{s}\right)$ were much less sensitive (Table 3$)$. Parameters $\bar{t}_{q}, \bar{t}_{s}, P_{q}$, and $P_{s}$ had low sensitivity, which suggests that a steadystate approximation for these parameters may be all that can be achieved with acceptable confidence.

In addition to having the highest sensitivity, $m_{q}, m_{s}$, and $b_{q}$ all were highly correlated $(>0.99)$, whereas all other parameter combinations had correlation coefficients of less than 0.85. Because $m_{q}$ and $m_{s}$ had similar absolute values (Table 2 ), it might be possible to combine these parameters and assume that $m_{s}=-m_{q}$, which might further constrain confidence intervals. This resulted in a much poorer model fit, much larger confidence intervals, and more parameter combinations that were highly correlated. This may have resulted because these parameters had relatively high sensitivity and needed to be estimated independently despite the high correlation. These results indicate that too few parameters, as well as too many, can result in a poorly posed problem.

To test the reliability of parameter convergence and uniqueness of solution, different initial parameter values were used to assure that the parameter estimation process would consistently result in the same values. PEST was executed twice, where all of the best-fit parameter values (Table 2 ) were divided by 2.0 for the first execution and multiplied by 2.0 for the second. Both executions resulted in the same best-fit parameter values as those listed in Table 2.

\section{Discussion}

The estimate of the long-term flow fraction was compared to results of an independent model for verification. A well withdrawing water with a wide distribution of ages results in different apparent

\section{Table 3}

Parameter sensitivity analysis showing the relative fractional change (RFC) in sum of the squared weighted residual (SSWR) resulting from parameter RFCs of -0.1 and 0.1 .

\begin{tabular}{lll}
\hline Parameter & Parameter RFC $=-0.1$ & Parameter RFC $=0.1$ \\
\hline $\bar{t}_{q}$ & 2.47 & 1.55 \\
$\bar{t}_{s}$ & 20.05 & 9.49 \\
$P_{q}$ & 0.27 & 0.24 \\
$P_{s}$ & 0.01 & 0.01 \\
$m_{q}$ & 622.76 & 622.62 \\
$m_{s}$ & 322.90 & 323.50 \\
$b_{q}$ & 473.86 & 474.78 \\
$\Psi_{q}$ & 1.00 & 1.00 \\
$\Psi_{s}$ & 0.05 & 0.05 \\
\hline
\end{tabular}

ages for the three CFCs based on a piston-flow model, which is characteristic of binary mixtures of water younger and older than 50 years (Plummer and Busenberg, 1999). Excluding other sources of error, inconsistency of these three apparent ages indicates that piston flow is a poor assumption, which is the case for well RC11, where the three apparent ages were separated by as much as 10 years for the 2005 samples. True piston flow would result in the same age for the three CFCs. For non-piston flow cases, Plummer et al. (2006) developed a simple binary mixing model to estimate the old fraction ( $>50$ years), which is valid if that fraction is not dominant (Corcho Alvarado et al., 2007). Although the binary mixing model treats the younger fraction as a single end member, results of this method can partially be compared to those of the convolution model presented in this paper because both methods estimate the older fraction. Thus using the binary mixing model as an independent confirmation, the long-term fraction was estimated to be in the range of $0.19-0.63$, which is similar to the range for the convolution model of $0.28-0.73$.

Assumptions regarding the exact flow and storage components that contribute to quick flow and slow flow were not build into the model (e.g., the proportion of epikarst water contributing to a particular flow domain was not explicitly described by the model). However, the estimated age distribution may provide general information about aquifer characteristics and flow components. The quick-flow domain (Fig. 4) probably contains conduit flow but also could include a considerable amount of epikarst water, as described by Aquilina et al. (2006), and annex-system flow because the ages were as much as 2 years. Also conduit/annex exchange may have occurred anywhere along the flow path.

There are several possible explanations for the slow-flow domain. First, this could be interpreted as annex-system flow, but the large separation between the ages of quick and slow flow suggest that this is unlikely for a hydraulically connected system of conduits and annex system. Second, slow flow could represent water from aquitards or the rock matrix as discussed by Bethke and Johnson (2002), who indicate that groundwater contributions from these can be large despite very low permeability.

Third, as previously described the overlying Minnelusa aquifer also is recharged by Spring Creek. The confining layers at the base of this aquifer could cause delayed recharge to the Madison aquifer as groundwater seeps slowly downward. This combined with epikarst storage in the buried Madison aquifer (previously described) might account for the decades-old water of the slow-flow domain. As an example, tritium concentrations in cave drip in Israel indicated greatly varying groundwater ages of as much as several decades (Even et al., 1986). Delayed storage in epikarst also has been discussed by Long (2009) in the northern Black Hills and elsewhere by Pinault et al. (2001), and regional paleowater mixed with recent recharge was described by Plummer et al. (1998).

Fourth, although recharge from direct precipitation is a small component of recharge to the Madison Limestone outcrop, direct precipitation falling on adjacent outcrops (the Minnelusa Formation to the east or fractured Precambrian rocks to the west) might infiltrate, then seep downward or upward into the Madison aquifer. This possibility was evaluated with a model modification to the tritium input function because this function for precipitation is different from that of streamflow. Results indicated that the spectral range of slow-flow age was within 1 year of previous results. The quick-flow fraction was within \pm 0.03 of previous results for all time steps; the slow and long-term fractions were as much as 0.17 less and 0.14 greater, respectively, than previous results; and overall temporal trends were similar. Modeled concentrations were within $\pm 5 \%$ of previous results. Thus, this fourth possibility for the slow-flow domain changed model results little.

The long-term component most likely results from the rock matrix, overlying aquitard, or underlying aquitard(s). 
Although the specific combination of storage mechanisms that are responsible for the quick-flow/slow-flow age separation cannot be determined from model results, it is evident that there is organization to the aquifer and that multiple flow components exist and are distinct. The karst groundwater system can be interpreted as having or being influenced by at least two reservoirs with considerably different residence times. The quantification of these is useful when considering quick transport and persistence of contaminants originating in the sinking stream. Understanding the influences of pumping and hydraulic head on the relative flow fractions is useful for assessing solute transport issues, particularly those related to quick flow.

Hydrologic models are merely approximations of physical phenomena. The estimated age distribution for the model application is useful as a general assessment of flow domains but does not identify the exact storage sources for the different flow domains, which mainly is left to interpretation based on knowledge of the system. The potential error associated with the different assumptions of the recharge source for slow flow should be considered. Several assumptions were built into this model: (1) the age distribution can be approximated by parametric functions, (2) $\bar{t}$ and $P$ are constant in time, (3) quick flow is less than 2 years old, and (4) the relative fractions of quick and slow flow are proportional to hydraulic head and pumping. Also, the actual age distribution probably is more varied than any parametric function, and ages of water not indicated by the modeled age distribution may have been present in samples. Parameterization possibly could be increased with additional tracers or greater sampling frequency. Application of this method is limited to cases where the tracer input functions are known or can be estimated, and prior knowledge of the hydrologic system may be needed to properly apply model assumptions and constraints.

Information gained from the age distribution pertains to annual or biannual dynamics and may provide a useful assessment of groundwater age and flow domains on a scale of years to decades but does not represent short-term events, nonlinearities, and threshold effects except for their cumulative effects. It was not possible to assess transient characteristics originating from the medium itself because dispersive properties were assumed constant at large time-scales and thus have no effect on quick-flow in response to individual rain events. Further hypothesis testing related to the level of parameterization warranted or the effects of limited data could be conducted if additional data were available by sequestering some of the data as a comparison to cases of limited data.

\section{Conclusions}

Convolution modeling is a useful approach that is well suited to estimate the distribution of groundwater age for two-domain flow in karst aquifers based on environmental tracer data. Inverse modeling and uncertainty assessment not only are useful for objectively estimating parameters, but also for determining the number of parameters that should be included based on the quality and quantity of measurements and the relative influence of the different tracers for a particular application. By considering these factors along with other hydrologic information, an appropriate level of model parameterization can be selected to help gain useful information from the model.

Chlorofluorocarbons (CFCs) and tritium $\left({ }^{3} \mathrm{H}\right)$ are complimentary tracers because of the differences in their atmospheric input functions. A basic framework for a quasi-transient convolution model for two-domain flow was designed to provide an acceptable level of statistical confidence in parameter estimates when only CFC and ${ }^{3} \mathrm{H}$ data are available. Because these are common tracers used for dating groundwater less than 50 years old, this model could have many potential applications.

In a model application to the Madison aquifer in the Black Hills of South Dakota, the age distribution and transient parameters for water from a pumped well were estimated, where simulated temporal changes in the relative flow-domain fractions were proportional to pumping and hydraulic head. A bimodal age distribution was modeled to represent quick and slow flow that is less than 50 years old. Long-term flow ( $>50$ years old) was estimated as the remainder of the quick-flow and slow-flow fractions, which were estimated to be in the range of $0-2$ and 26-41 years, respectively. Results indicated that ${ }^{3} \mathrm{H}$, when used in combination with CFC data, was the most critical tracer for parameter estimation and uncertainty quantification, and CFC-113 was least influential.

In this application, the quick-flow fraction probably represents a combination of conduit flow and epikarst storage. The slow-flow fraction may be the result of several storage mechanisms including: (1) aquitards, (2) rock matrix, (3) streamflow sinking into and stored in the overlying aquifer and the buried epikarst of the Madison aquifer, and (4) infiltration of direct precipitation to adjacent aquifers in hydraulic connection with the Madison aquifer. Quantification of the residence times and relative flow fractions of the major storage and flow components is useful when considering quick transport and persistence of contaminants. The influences of pumping and hydraulic head on the quick-flow fraction is a useful insight for assessing short-term contaminant transport issues.

\section{Acknowledgements}

This study was conducted in cooperation with the city of Rapid City, who provided assistance in data collection efforts and well pumping rates. The authors are indebted to Earl Greene and Allen Shapiro for initiating the data collection effort for CFCs and tritium in 1994 as part of the cooperative program with Rapid City and the US Geological Survey. The South Dakota Department of the Environment and Natural Resources assisted in water-level measurements.

\section{Appendix A}

\section{A.1. Estimating long-term ${ }^{3} \mathrm{H}$ concentrations in Spring Creek}

${ }^{3} \mathrm{H}$ concentrations were estimated for Spring Creek at 6-month intervals for the period 1953-2005 (Fig. 1). This record was used as the Spring Creek recharge ${ }^{3} \mathrm{H}$ input function for the groundwater age model for well RC11. For the four Spring Creek ${ }^{3} \mathrm{H}$ samples (Table 1 ), ${ }^{3} \mathrm{H}$ concentrations in the base-flow component were estimated. Then the distribution of groundwater age for Spring Creek base flow was modeled and calibrated to the estimated base-flow concentrations for the samples. Based on this model, daily base-flow and event-flow ${ }^{3} \mathrm{H}$ concentrations were estimated for Spring Creek for 1953-2005, and 6-month average concentrations were calculated. Similar methods have been used by Michel (1992) and Amin and Campana (1996) to model ${ }^{3} \mathrm{H}$ concentrations in streams.

A convolution model and parameter estimation procedure similar to that described in the main text was used. The age of groundwater discharging to the surface as stream base flow was approximated using the exponential distribution (Amin and Campana, 1996):

$g(\tau)=\frac{1}{\bar{t}} \exp \left[\frac{-\tau}{\bar{t}}\right]$. 
Table 4

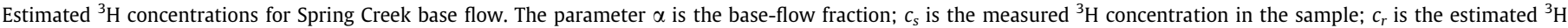
concentration in precipitation; $c_{b}$ is the ${ }^{3} \mathrm{H}$ concentration in base flow; and $c(t)$ is the tracer concentration in stream base flow at time $t$.

\begin{tabular}{|c|c|c|c|c|c|c|c|}
\hline \multirow[t]{2}{*}{ Sample date } & \multicolumn{6}{|c|}{${ }^{3} \mathrm{H}$ concentration in tritium units (TU) } & \multirow[t]{2}{*}{ Error } \\
\hline & $(\alpha)$ & $\left(c_{s}\right)$ & $\left(c_{r}\right)$ & $\left(c_{b}\right)$ & $c(t)$ & Residual $c(t)-\left(c_{b}\right)$ & \\
\hline 27 September 1993 & 0.88 & 29.7 & 7.9 & 31.2 & 31.6 & 0.4 & $1.3 \%$ \\
\hline 9 September 1996 & 0.84 & 25.1 & 7.8 & 28.1 & 24.8 & -3.3 & $-11.7 \%$ \\
\hline 6 June 2000 & 0.88 & 19.1 & 9.0 & 19.8 & 18.9 & -0.9 & $-4.5 \%$ \\
\hline 6 May 2005 & 0.71 & 10.7 & 7.3 & 10.9 & 12.9 & 2.0 & $18.3 \%$ \\
\hline
\end{tabular}

In this model the tracer age $\tau$ is assumed to be proportional to the distance from the infiltration point to the point of discharge into the stream, which is valid for the catchment upstream from the Madison Limestone consisting primarily of fractured Precambrian rocks.

Typically, hydrograph separation methods assume that concentrations in streamflow result from a binary mixture of event flow and groundwater inflow, or base flow (e.g., Michel, 1992). In this case, the ${ }^{3} \mathrm{H}$ concentration of event flow is equal to that of precipitation, and the concentration of base flow is unknown. The estimated 6-month ${ }^{3} \mathrm{H}$ concentrations in precipitation for the Black Hills (Fig. 1) were used for the event-flow component. Flow in Spring Creek upstream from the Madison Limestone outcrop was measured continuously by the US Geological Survey from 1 October 1986 to the present (Fig. 2; station 06407500; US Geological Survey, 2008). Prior to 1 October 1986, flow at this station was estimated as a proportion of measured flow in Rapid Creek (Fig. 2; station 06412200; US Geological Survey, 2008). The daily base-flow fraction of Spring Creek then was estimated by using the base-flow separation program, HYSEP (Sloto and Crouse, 1996). Finally, the estimated ${ }^{3} \mathrm{H}$ concentrations in base flow were calculated for the four Spring Creek samples (Table 1) using a binary mixing model of the form

$c_{s}=\alpha c_{b}+(1-\alpha) c_{r}$,

where $c_{s}$ is the measured ${ }^{3} \mathrm{H}$ concentration in the sample; $\alpha$ and $1-$ $\alpha$ are the 6-month average base-flow and event-flow volumetric fractions, respectively; $c_{b}$ is the ${ }^{3} \mathrm{H}$ concentration in base flow; and $c_{r}$ is the estimated ${ }^{3} \mathrm{H}$ concentration in precipitation (Table 4).

For the spring creek analysis, the estimated ${ }^{3} \mathrm{H}$ in precipitation for the Black Hills (Fig. 1) was used as $c_{i n}(t)$ in Eq. (1). The system output $c(t)$ is the tracer concentration in stream base flow at time $t$. The parameter $\bar{t}$ (Eq. (6)) was estimated by the same iterative parameter estimation process used to estimate the age distribution for well RC11. Steady-state conditions were assumed for the Spring Creek model, and modeled ${ }^{3} \mathrm{H}$ concentrations in base flow, $c(t)$, were calibrated to the estimated values $\left(c_{b}\right)$. The calibrated value of $\bar{t}$ was $1.94 \times 10^{-2}$, with $95 \%$ confidence intervals of $9.66 \times$ $10^{-3}$ and $3.89 \times 10^{-2}$.

A long-term daily record of ${ }^{3} \mathrm{H}$ concentrations for Spring Creek base flow was calculated by convolution (Eq. (1)) using the calibrated value of $\bar{t}$. The estimated record of ${ }^{3} \mathrm{H}$ in precipitation for the Black Hills (Fig. 1) was used as the input tracer concentration $c_{i n}(t)$. Eq. (7) then was applied to calculate the daily whole-water ${ }^{3} \mathrm{H}$ concentrations in Spring Creek $\left(c_{s}\right)$ from the modeled concentrations for base flow, event flow (precipitation), and the base-flow fraction estimated by HYSEP. Six-month averages for this record were then calculated from the daily values (Fig. 1).

\section{References}

Amin, I.E., Campana, M.E., 1996. A general lumped parameter model for the interpretation of tracer data and transit time calculation in hydrologic systems. Journal of Hydrology 179 (1-4), 1-21.

Anderson, M.P., Woessner, W.W., 1992. Applied Groundwater Modeling. Academic Press, San Diego, California.
Anderson, M.T., Driscoll, D.G., Williamson, J.E., 1999. Ground-water and surfacewater interactions along Rapid Creek near Rapid City, South Dakota. US Geological Survey Water Resources Investigations Report 98-4214. <http:// pubs.er.usgs.gov/usgspubs/wri/wri984214>.

Aquilina, L., Ladouche, B., Dörfliger, N., 2006. Water storage and transfer in the epikarst of karstic systems during high flow periods. Journal of Hydrology 327 (3-4), 472-485.

Bethke, C.M., Johnson, T.M., 2002. Paradox of groundwater age. Geological Society of America Bulletin 30 (2), 107-110.

Böhlke, J.K., 2004. TRACERMODEL1. Excel workbook for calculation and presentation of environmental tracer data for simple groundwater mixtures. In: IAEA Guidebook on the Use of Chlorofluorocarbons in Hydrology. IAEA, Vienna.

Bredehoeft, J., Kendy, E., 2008. Strategies for offsetting seasonal impacts of pumping on a neardy stream. Ground Water 46 (1), 23-29.

Cook, P.G., Herczeg, A.L. (Eds.), 2000. Environmental Tracers in Subsurface Hydrology. Kluwer Academic Publishers, Boston, Massachusetts, USA.

Cook, P.G., Solomon, D., Sanford, W.E., Busenberg, E., Plummer, L.N., Poreda, R., 1996. Inferring shallow groundwater flow in saprolite and fractured rock using environmental tracers. Water Resources Research 32 (6), 1501-1509.

Corcho Alvarado, J.A., Purtschert, R., Barbecot, F., Chabault, C., Rueedi, J., Schneider V., Aeschbach-Hertig, W., Kipfer, R., Loosli, H.H., 2007. Constraining the age distribution of highly mixed groundwater using ${ }^{39} \mathrm{Ar}$ : a multiple environmental tracer $\left({ }^{3} \mathrm{H} /{ }^{3} \mathrm{He},{ }^{85} \mathrm{Kr}\right.$, ${ }^{39} \mathrm{Ar}$, and $\left.{ }^{14} \mathrm{C}\right)$ study in the semiconfined Fontainebleau Sands Aquifer (France). Water Resources Research 43 (3). doi:10.1029/ 2006WR00509.

Denic-Jukic, V., Jukic, D., 2003. Composite transfer functions for karst aquifers. Journal of Hydrology 274 (1-4), 80-94.

Doherty, J., 2006. Pest: Model-Independent Parameter Estimation. User Manual 5th ed. Variously Paged, Watermark Numerical Computing. <http://www.sspa.com/ pest>.

Driscoll, D.G., Hamade, G.R., Kenner, S.J., 2000. Summary of precipitation data for the Black Hills area of South Dakota, water years 1931-98. US Geological Survey Open File Report 00-329. <http://pubs.er.usgs.gov/usgspubs/ofr/ ofr00329>

Driscoll, D.G., Carter, J.M., Williamson, J.E., Putnam, L.D., 2002. Hydrology of the Black Hills area, South Dakota. US Geological Survey Water Resources Investigations Report 02-4094. <http://pubs.er.usgs.gov/usgspubs/wri/ wri024094>

Even, H., Carmi, I., Magaritz, M., Gerson, R., 1986. Timing the transport of water through the upper vadose zone in a karstic system above a cave in Israel. Earth Surface Processes and Landforms 11 (2), 181-191.

Ford, D.C., Lundberg, J., Palmer, A.N., Palmer, M.V., Dreybrodt, W., Schwarcz, H.P., 1993. Uranium-series dating of the draining of an aquifer: the example of Wind Cave, Black Hills, South Dakota. Geological Society of America Bulletin 105, 241-250.

Gallagher, M.R., Doherty, J., 2007. Parameter interdependence and uncertainty induced by lumping in a hydrologic model. Water Resources Research 43 (5). doi:10.1029/2006WR00534.

Goode, D.J., 1996. Direct simulation of groundwater age. Water Resources Research 32 (2), 289-296.

Greene, E.A., 1993. Hydraulic properties if the Madison aquifer system in the western Rapid City area, South Dakota. US Geological Survey Water Resources Investigations Report 93-4008. <http://pubs.er.usgs.gov/usgspubs/wri/ wri934008>.

Greene, E.A., 1997. Tracing recharge from sinking streams over spatial dimensions of kilometers in a karst aquifer. Ground Water 35 (5), 898-904.

Greene E.A., 1999. Characterizing recharge to wells in carbonate aquifers using environmental and artificially recharged tracers. In: Charleston, S.C. (Ed.) Proceedings of the Toxic Substances Hydrology Program, 8-12 March 1999. US Geological Survey Water Resources Investigations Report 99-4018-C. <http:// pubs.er.usgs.gov/usgspubs/wri/wri994018C>.

Gries, J.P., 1996. Roadside Geology of South Dakota. Mountain Press Publishing Company, Missoula, Montana, US.

Hill, M.C., 2006. The practical use of simplicity in developing ground water models. Ground Water 44 (6), 775-781.

Hortness, J.E., Driscoll., D.G., 1998. Streamflow losses in the Black Hills of western South Dakota. US Geological Survey Water Resources Investigations Report 984116. <http://pubs.er.usgs.gov/usgspubs/wri/wri984116>.

Levenberg, K., 1944. A method for the solution of certain non-linear problems in least squares. Quarterly of Applied Mathematics 2, 164-168. 
Long, A.J., 2009. Hydrograph separation for karst watersheds using a two-domain rainfall-discharge model. Journal of Hydrology 364 (3-4), 249-256.

Long, A.J., Putnam, L.D., 2002. Flow-system analysis of the Madison and Minnelusa aquifers in the Rapid City area, South Dakota - conceptual model. USGS Water Resources Investigations Report 02-4185.

Long, A.J., Putnam, L.D., 2006. Translating CFC-based piston ages into probability density functions of ground-water age in karst. Journal of Hydrology 330 (3-4), 735-747.

Mahler, B.J., Massei, N., 2007. Anthropogenic contaminants as tracers in an urbanizing karst aquifer. Journal of Contaminant Hydrology 91 (1-2), 81-106.

Maloszewski, P., Zuber, A., 1991. Influence of matrix diffusion and exchange reactions on radiocarbon ages in fissured carbonate aquifers. Water Resources Research 27 (8), 1937-1945.

Maloszewski, P., Zuber, A., 1996. Lumped parameter models for the interpretation of environmental tracer data. In: Manual on Mathematical Models in Isotope Hydrology, TECDOC 910, 9-58. IAEA, Vienna.

Mangin, A., 1994. Karst hydrogeology. In: Gilbert, J. (Ed.), Ground-Water Ecology. Elsevier, New York, pp. 43-67.

Marquardt, D.W., 1963. An algorithm for least-squares estimation of nonlinear parameters. Journal of the Society for Industrial and Applied Mathematics 11 (2), 431-441.

Michel, R.L., 1992. Residence times in river basins as determined by analysis of long-term tritium records. Journal of Hydrology 130 (1-4), 367-378.

Naus, C.A., Driscoll, D.G., Carter, J. M., 2001. Geochemistry of the Madison and Minnelusa aquifers in the Black Hills area, South Dakota. USGS Water Resources Investigations Report 01-4129.

Olsthoorn, T.N., 2008. Do a bit more with convolution. Ground Water 46 (1), 13-22.

Oster, H., Sonntag, C., Munnich, K.O., 1996. Groundwater age dating with chlorofluorocarbons. Water Resources Research 32 (10), 2989-3001.

Ozyurt, N.N., Bayari, C.S., 2005. LUMPED UnSteady; a Visual Basic code of unsteadystate lumped-parameter models for mean residence time analyses of groundwater systems. Computers and Geosciences 31 (3), 329-341.

Palmer, A.N., 1991. Origin and morphology of limestone caves. Geological Society of America Bulletin 103, 1-21.

Pinault, J.L., Plagnes, V., Aquilina, L., Bakalowicz, M., 2001. Inverse modeling of the hydrological and the hydrochemical behavior of hydrosystems; characterization of karst system functioning. Water Resources Research 37 (8), 2191-2204
Plummer, L.N., Busenberg, E., 1999. Chlorofluorocarbons. In: Cook, P.G., Herczeg, A.L. (Eds.), Environmental Tracers in Subsurface Hydrology. Kluwer Academic Press, Boston, Massachusetts, pp. 441-478.

Plummer, L.N., Busenberg, E., 2006. Chlorofluorocarbons in the atmosphere, In: Use of Chlorofluorocarbons in Hydrology - A Guidebook. IAEA, Vienna. pp. 9-14 <http://www-pub.iaea.org/MTCD/publications/PDF/Pub1238_web.pdf>.

Plummer, L.N., Busenberg, E., Drenkard, S., Schlosser, P., Ekwurzel, B., Weppernig, R., McConnell, J.B., Michel, R.L., 1998. Flow of river water into a karstic limestone aquifer -2 . Dating the young fraction in groundwater mixtures in the Upper Floridan aquifer near Valdosta, Georgia. Applied Geochemistry 13 (8), 1017 1043.

Plummer, L.N., Busenberg, E., Han, L.F., 2006. CFCs in binary mixtures of young and old groundwater. In: Use of Chlorofluorocarbons in Hydrology - A Guidebook. IAEA, Vienna. pp. 59-72. <http://www-pub.iaea.org/MTCD/publications/PDF/ Pub1238_web.pdf>.

Putnam, L.D., Long, A.J., 2007a. Analysis of ground-water flow in the Madison Aquifer using fluorescent dyes injected in Spring Creek and Rapid Creek near Rapid City, South Dakota, 2003-04. USGS Scientific Investigations Report 20075137.

Putnam, L.D., Long, A.J., 2007b. Characterization of ground-water flow and water quality for the Madison and Minnelusa Aquifers in northern Lawrence County South Dakota. USGS Scientific Investigations Report 2007-5001.

Rahn, P.H., Gries, J.P., 1973. Large springs in the Black Hills, South Dakota and Wyoming, South Dakota Geological Survey Report of Investigations 10.

Sloto, R.A., Crouse, M.Y., 1996. HYSEP: a computer program for streamflow hydrograph separation and analysis. USGS Water Resources Investigations Report 96-4040.

Strobel, M.L., Jarrell, G.J., Sawyer, J.F., Schleicher, J.R., and Fahrenbach, M.D., 1999. Distribution of hydrogeologic units in the Black Hills Area, South Dakota. USGS Hydrologic Investigations Atlas HA-074.

US Geological Survey, 2008. National Water Information System. <http:// waterdata.usgs.gov/nwis>.

Varni, M., Carrera, J., 1998. Simulation of groundwater age distributions. Water Resources Research 34 (12), 3271-3281.

Zinn, B.A., Konikow, L.F., 2007. Potential effects of regional pumpage on groundwater age distribution. Water Resources Research 43, W06418. doi:10.1029/2006WR004865. 